\title{
Insights into the diet of beaked whales from the atypical mass stranding in the Canary Islands in September 2002
}

\author{
M.B. Santos**, V. Martin, M. Arbelof, A. Fernández and G.J. Pierce* \\ *School of Biological Sciences (Zoology), University of Aberdeen, Tillydrone Avenue, Aberdeen, AB24 2TZ, UK. 'Instituto \\ Español de Oceanografía, Centro Costero de Vigo, Cabo Estay, Canido, 36200 Vigo, Spain. *Sociedad para el Estudio de los Ce- \\ táceos en el Archipiélago Canario (SECAC)/Museo de Cetáceos de Canarias, Edif. Antiguo Varadero lera planta, local 8B, Urb. \\ Puerto Calero 35571, Yaiza, Lanzarote, Spain. SInstitute for Animal Health (IUSA), Veterinary School, University of Las Palmas

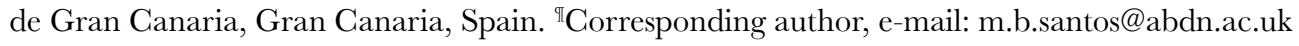

\begin{abstract}
Stomach contents were analysed from three species of beaked whales which mass-stranded shortly after a naval exercise conducted in the Canary Islands in September 2002. Animals from such mass strandings often contain freshly ingested food in their stomachs and can provide a more reliable guide to feeding habits than other strandings. Food remains recovered from seven Cuvier's beaked whales (Ziphius cavirostris) consisted mainly of oceanic cephalopods, the most numerous being Taonius pavo, Histioteuthis sp., Mastigoteuthis schmidti and Octopoteuthis sicula. Many of the cephalopod species found in the diet appear to undertake daily vertical migrations, being found in shallower waters during the night and moving to deeper waters during the day. Single specimens of Blainville's beaked whale (Mesoplodon densirostris) and Gervais' beaked whale (Mesoplodon europaeus) had eaten both fish and cephalopod prey. The most numerous prey remains belonged to gadid fish and viperfish (Chauliodus sp.) respectively. These results are consistent with the limited published data on diet in these species, with Mesoplodon species having a relatively higher proportion of fish in the diet whereas Ziphius specialises on cephalopods.
\end{abstract}

\section{INTRODUGTION}

The Canary Islands archipelago, with 27 different cetacean species recorded, has one of the richest and most diverse cetacean faunas in the north-east Atlantic. Due to the absence of a continental shelf around the islands, oceanic species are common. Five species of beaked whales (Ziphiidae) belonging to three genera (Ziphius, Mesoplodon and Hyperoodon) have been recorded in the area (Martín et al., 1992; Martín \& Urquiola, 2001). On 24 September 2002, a mass stranding of beaked whales took place off the islands of Fuerteventura and Lanzarote (see Figure 1). A total of 14 individual whales washed ashore. These belonged to three species: Cuvier's beaked whale, Ziphius cavirostris Cuvier, 1823, Gervais' beaked whale, Mesoplodon europaeus (Gervais, 1855) and Blainville's beaked whale, Mesoplodon densirostris (Blainville, 1817). For further details of the stranding event see Fernández et al. (2004, 2005).

The mass stranding was considered 'atypical' since it involved several species and the strandings occurred over an extended geographical area (in a relatively short period of time) instead of in a single location. Of the 14 animals involved in the event, five were found dead and nine stranded alive - of which three died shortly afterwards and six were refloated. Over four days from the discovery of the first animal, 11 carcasses were recovered: nine Cuvier's beaked whales, one Blainville's beaked whale and one Gervais' beaked whale.
Little information exists on the diet of beaked whales. In general, they are believed to feed mainly on cephalopods (e.g. Lefkaditou \& Poulopoulos, 1998; Blanco \& Raga, 2000; Santos et al., 2001; MacLeod et al., 2003), although consumption of fish and crustaceans has also been recorded (e.g. Clarke, 1986a; Debrot \& Barros, 1994). Only two previous studies have examined the diet of beaked whales in the Canaries. Hernández-García (1995) described the stomach contents of two stranded Cuvier's beaked whales, while Martin et al. (1990) described dietary findings for Gervais' beaked whales.

The aim of this paper is to present new information on the feeding habits of three species of beaked whales in the Canary Islands, based on analysis of the stomach contents of nine of the animals stranded on 24 September 2002: seven Cuvier's beaked whales, one Gervais' beaked whale and one Blainville's beaked whale. Dietary results for the Canary Islands are compared with those for other parts of the world.

\section{MATERIALS AND METHODS}

A team formed by members of the Institute for Animal Health (IUSA), the Veterinary School of the University of Las Palmas de Gran Canaria and the Sociedad para el Estudio de los Cetáceos en el Archipiélago Canario (SECAC) carried out necropsies of the whales stranded on 24 September 2002, and collected the stomach contents together with samples from 


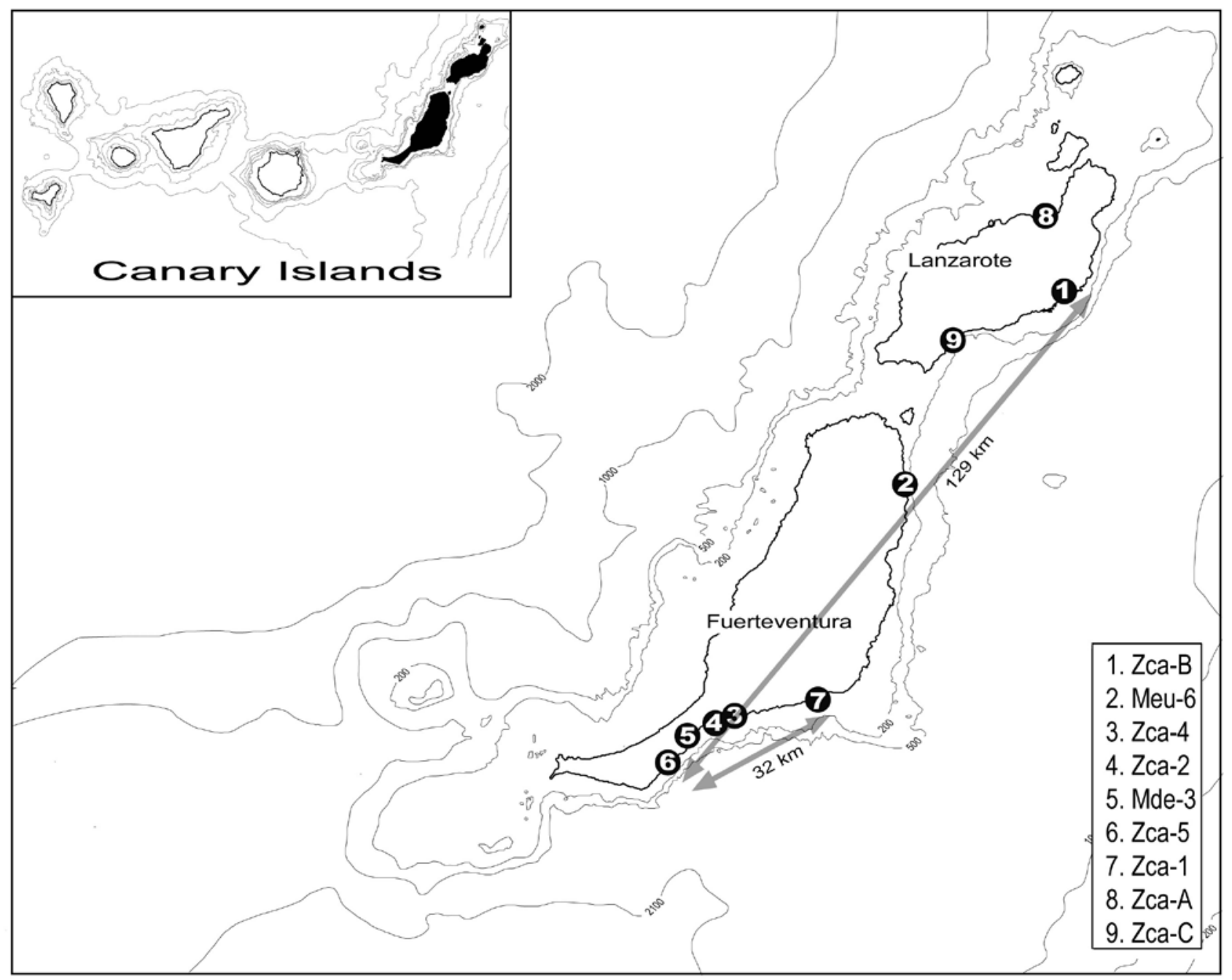

Figure 1. Map of the study area showing the location of the strandings and the distances between strandings.

other tissues (e.g. gonad samples to determine maturity status, etc.). Biological information on the whales for which stomach contents were obtained is summarized in Table 1.

In all cases, stomach contents consisted mainly of cephalopod mandibles (beaks) and eye lenses. Fish bones and otoliths, crustacean exoskeletons and cephalopod flesh were also recovered. Cephalopod beaks and fish hard parts were identified using published guides (Clarke, 1986b; Härkönen, 1986; Smale et al., 1995) and reference collections of beaks of oceanic cephalopods, fish bones and otoliths.

The minimum number of individual fish and cephalopods present in each stomach was estimated from all identifiable remains (e.g. the number of lower or upper beaks, whichever was higher, for cephalopods, and the number of otoliths/ maxillary bones divided by 2 for fish). Most of the crustacean remains were too digested to be identified to species level. When individual crustaceans could not be distinguished, the minimum number present was assigned a value of one. All undamaged lower beaks and otoliths were measured using a microscope fitted with an eyepiece graticule: lower rostral length (LRL) for decapod cephalopod beaks, lower hood length (LHL) for octopus beaks, and length (OL) for fish otoliths. Original prey size (length and weight) was estimated from these hard part measurements, using published regressions (e.g. Clarke, 1986; Brown \& Pierce,
1998; Merella et al., 1997). For crustacean remains, where possible, weights were measured directly.

Results on dietary importance of each prey species are summarized in terms of their numerical importance and contribution to estimated total prey biomass.

\section{RESULTS}

\section{Species composition and age-class of the examined animals}

Stomach contents were collected from seven Cuvier's beaked whales, one Gervais' beaked whale and one Blainville's beaked whale. The Blainville's beaked whale was accompanied by a calf (see Table 1).

Most of the whales were found in a very fresh state (it is estimated they had died less than $10 \mathrm{~h}$ before they were examined) with the exception of whales Zca-1 and Zca-A which were moderately decomposed $( \pm 24 \mathrm{~h}$ after death) and whale $\mathrm{Zca}-\mathrm{C}$ which was found in an advanced stage of decomposition $(>48 \mathrm{~h}$ ). Flesh of whale $\mathrm{Zca}-\mathrm{A}$ had been partially eaten by sharks. All whales appeared to have been in good body condition, with the exception of whale Zca-B, which was visibly emaciated. The necropsy of this last whale showed a high parasitic load (nematodes) in the stomach, and also a plastic sheet. The stomach of this specimen was the only one that did not contain fresh food remains. 







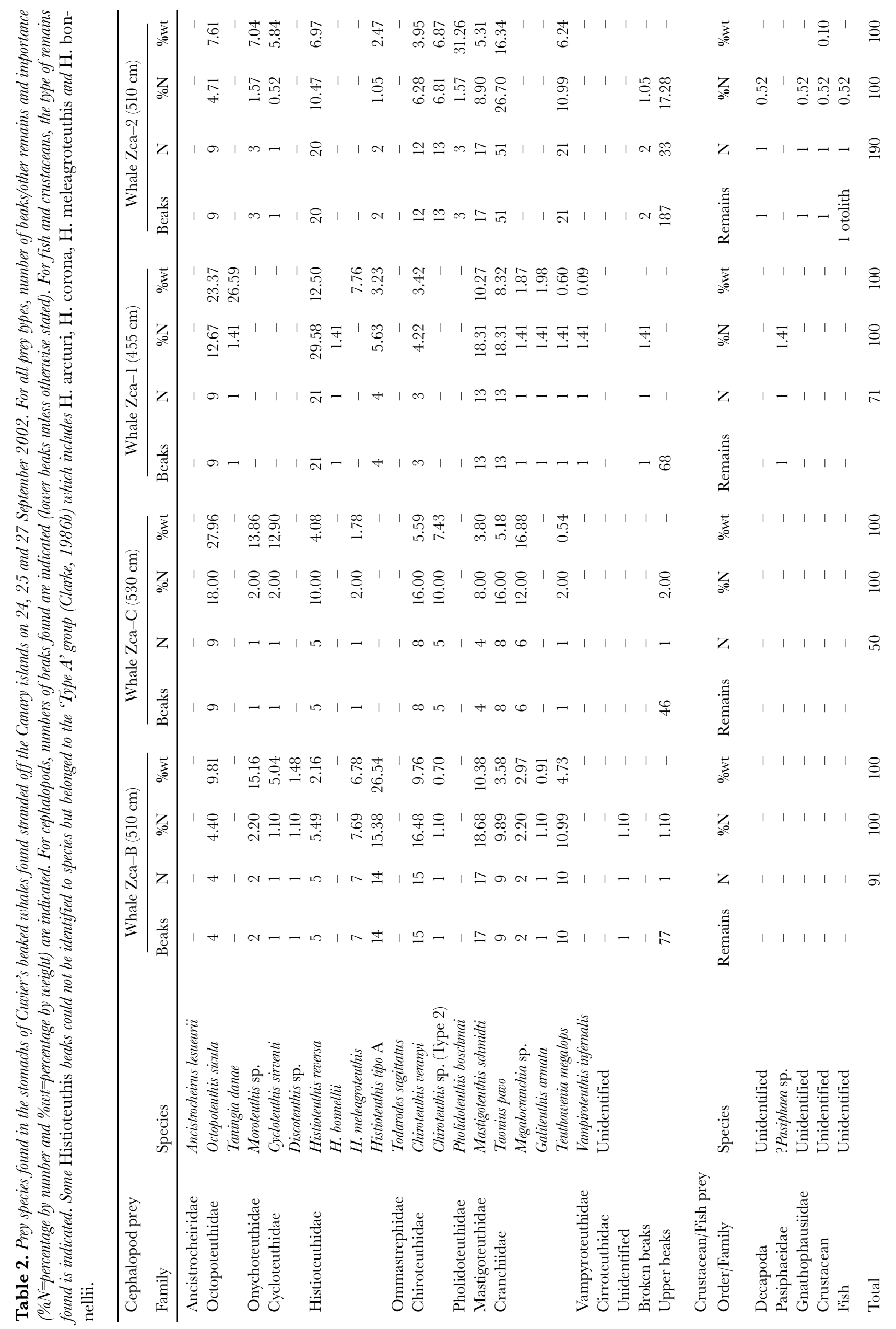




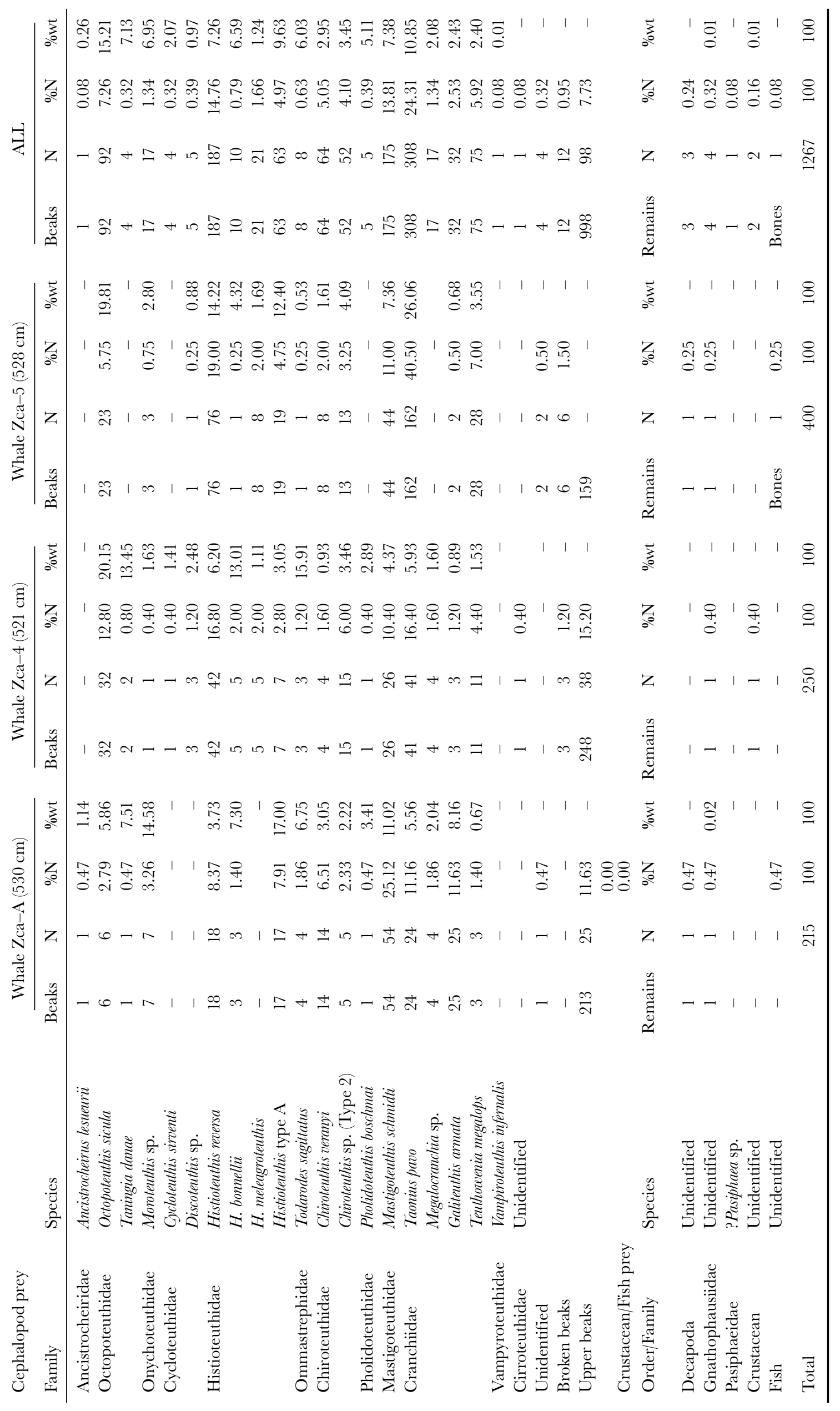


Table 3. Prey species found in the stomachs of Mesoplodon densirostris and M. europaeus found stranded off the Canary Islands on 24 September 2002. For all prey types, number of beaks/other remains and importance (\% $\mathrm{N}=$ percentage by number and \%wt=percentage by weight) are indicated. For cephalopods, numbers of beaks found are indicated (lower beaks unless otherwise stated). For fish and crustaceans, the type of remains found is indicated. Some Histioteuthis beaks could not be identified to species but belonged to the 'Type A' group (Clarke, 19866), which includes $\mathrm{H}$. arcturi, H. corona, H. meleagroteuthis and $\mathrm{H}$. bonnellii.

\begin{tabular}{|c|c|c|c|c|c|c|c|c|c|}
\hline \multirow{2}{*}{$\begin{array}{l}\text { Cephalopod prey } \\
\text { Family }\end{array}$} & \multirow[b]{2}{*}{ Species } & \multicolumn{4}{|c|}{ M. densirostris $(421 \mathrm{~cm})$} & \multicolumn{4}{|c|}{ M. europaeus $(441 \mathrm{~cm})$} \\
\hline & & Beaks & $\mathrm{N}$ & $\% \mathrm{~N}$ & \%wt & Beaks & $\mathrm{N}$ & $\% \mathrm{~N}$ & $\% w t$ \\
\hline Octopoteuthidae & Octopoteuthis sicula & 1 & 1 & 1.12 & 6.18 & - & - & - & - \\
\hline \multirow[t]{3}{*}{ Histioteuthidae } & Histioteuthis reversa & 1 & 1 & 1.12 & 1.51 & - & - & - & - \\
\hline & H. meleagroteuthis & 1 & 1 & 1.12 & 2.93 & - & - & - & - \\
\hline & Histioteuthis Type A & 1 & 1 & 1.12 & 1.32 & - & - & - & - \\
\hline Cranchiidae & Taonius pavo & 3 & 3 & 3.38 & 3.23 & 2 & 2 & 20.00 & 79.05 \\
\hline Unidentified & & - & - & - & - & - & - & - & - \\
\hline Broken beaks & & - & - & - & - & - & - & - & - \\
\hline Upper beaks & & 9 & 2 & 2.25 & - & 3 & 1 & 10.00 & - \\
\hline \multicolumn{10}{|l|}{ Crustacean prey } \\
\hline Family & Species & Remains & $\mathrm{N}$ & $\% \mathrm{~N}$ & $\%$ wt & Remains & $\mathrm{N}$ & $\% \mathrm{~N}$ & $\% w t$ \\
\hline Unidentified & & & 1 & 1.12 & & - & - & - & - \\
\hline \multicolumn{10}{|l|}{ Fish prey } \\
\hline Family & Species & Remains & $\mathrm{N}$ & $\% \mathrm{~N}$ & $\%$ wt & Remains & $\mathrm{N}$ & $\% \mathrm{~N}$ & $\% \mathrm{wt}$ \\
\hline Chauliodontidae & Chauliodus sp. & - & - & - & - & 12 bones & 6 & 60.00 & 29.05 \\
\hline \multirow[t]{2}{*}{ Myctophidae } & Lampadena sp. & - & - & - & - & 1 otolith & 1 & 10.00 & - \\
\hline & Unidentified & 12 otoliths & 6 & 6.75 & 0.15 & - & - & - & - \\
\hline Gadidae & Unidentified & 128 otoliths & 64 & 71.91 & 84.68 & - & - & - & - \\
\hline Unidentified & Eroded otoliths & 18 otoliths & 9 & 10.11 & - & - & - & - & - \\
\hline Total & & & 89 & 100 & 100 & & 10 & 100 & 100 \\
\hline
\end{tabular}

\section{Cuvier's beaked whales}

All seven Cuvier's beaked whales (whales Zca-A, Zca-B and Zca-C from Lanzarote and whales Zca-1, Zca-2, Zca4 and Zca-5 from Fuerteventura) had cephalopod beaks and eye lenses in their stomachs. Whale Zca-2 also had remains of crustaceans and a fish otolith in its stomach, while the stomachs of whales Zca-1, Zca-4 and Zca-A also contained cephalopod flesh and crustacean exoskeletons. Finally, whale Zca-5 also had remains of fish in its stomach (a few vertebrae and eye lenses). The number of cephalopod beaks found ranged from 46 upper and 49 lower beaks (whale Zca-C) to 160 upper and 397 lower beaks (whale Zca-5).

A minimum of 10 (whale Zca-2) and a maximum of 18 (whale Zca-4) cephalopod taxa were identified in the stomachs of Cuvier's beaked whales. The fish vertebrae found in the stomach of whale Zca-5 could not be identified to species level. Crustacean remains found in the stomach of whale Zca-5 included the well-preserved body of a decapod but the head was missing so it could not be identified further. In the stomach of whale Zca-1, the head of a decapod crustacean was identified as belonging to Pasiphaea sp. In the stomachs of whales Zca-2, Zca-4 and Zca-A some of the crustacean remains could be identified as Gnathophausiidae (Mysidacea), a family of giant (up to $35 \mathrm{~cm}$ ) deep-sea species.

Estimated sizes (dorsal mantle length, DML) of Taonius pavo ranged from 115 to $385 \mathrm{~mm}$ with a mode at $265 \mathrm{~mm}$ (Figure 2), as compared to $15-75 \mathrm{~mm}$ (mode $55 \mathrm{~mm}$ ) for Histioteuthis reversa, 45-155 mm (mode $125 \mathrm{~mm}$ ) for Mastigoteuthis schmidti and 85-295 mm (mode $175 \mathrm{~mm}$, Figure 2) for Octopoteuthis sicula (Table 1).
The reconstructed weight of the prey remains found in the stomachs of the Cuvier's beaked whales (taking into consideration that beaks and otoliths not identified did not contribute to the reconstructed weight so the final figure is an underestimation) ranged from nearly $8.5 \mathrm{~kg}$ (whale ZcaC) to more than $47.5 \mathrm{~kg}$ (whale $\mathrm{Zca}-4)$.

\section{Blainville's and Gervais' beaked whales}

The stomach of the single Blainville's beaked whale examined contained otoliths and bones of two different species of fish, identified as belonging to the families Gadidae and Myctophidae. Beaks from five cephalopod taxa: Octopoteuthis sicula, Histioteuthis reversa, $H$. meleagroteuthis, Histioteuthis Type A and Taonius pavo, cephalopod eye lenses and remains of one crustacean were also found in the stomach (Table 3).

The stomach of the Gervais' beaked whale contained fresh remains of cephalopods together with loose beaks, one fish otolith and some fish bones (Table 3). The bones were identified as dentaries (lower jaw bones) from the genus Chauliodus, two species of which are present in waters of the Canary Islands ( $C$. danae and $C$. sloani), both with very similar jaw bones. The fish otolith was from Lampadena sp. (Myctophidae), a genus that, as in the previous case, is represented by several species in the area (Whitehead et al., 1989).

Estimated sizes of the squid Taonius pavo ranged from 135 to $265 \mathrm{~mm}$ in the stomach of the Blainville's beaked whale and 285-305 $\mathrm{mm}$ in the Gervais' beaked whale (Table 1). In the case of the Blainville's beaked whale, reconstructed prey biomass totalled nearly $4 \mathrm{~kg}$, while for the Gervais' beaked whale summed prey biomass was less than $220 \mathrm{~g}$. 


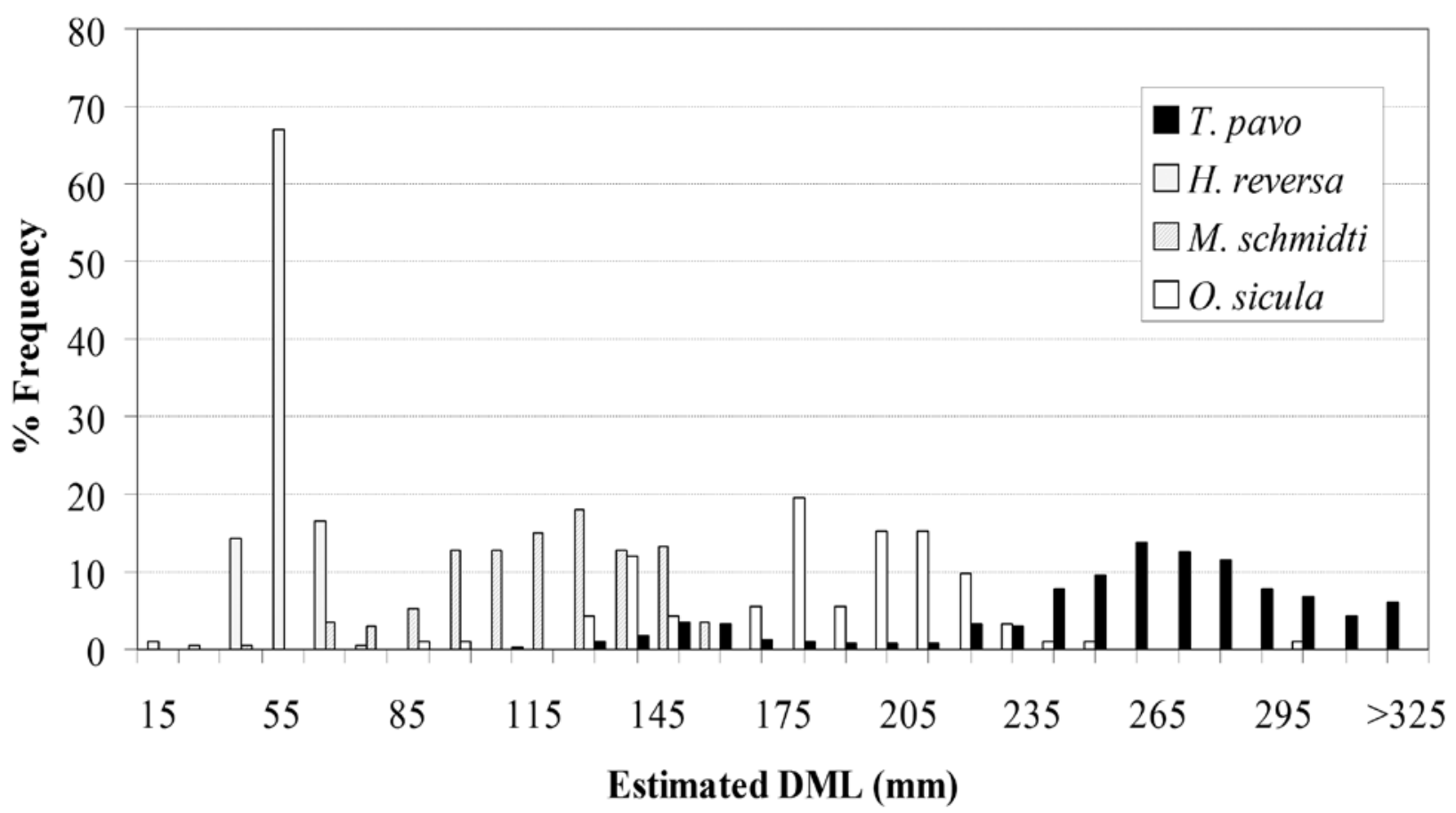

Figure 2. Frequency distribution of estimated size (DML, dorsal mantle length) of main prey species in the stomachs of Cuvier's beaked whales found stranded on 24, 25 and 27 September 2002.

\section{DISGUSSION}

The information available on the diet of beaked whales is very limited and comes almost exclusively from the analysis of the few animals that have been found stranded in different parts of the world. Of the three beaked whale species analysed in the present study, the diet of Cuvier's beaked whale is perhaps the best studied due to the relatively large number of specimens available from strandings and the existence, for a period, of a 'smaller whale' fishery in Japan for this species (Omura et al., 1955; Nishiwaki \& Oguro, 1972). Cuvier's beaked whales also have a wider geographical distribution than other species.

In the Canary Islands, Hernández-García (1995) analysed the stomach contents of two Cuvier's beaked whales stranded in 1991. The author found remains of fish and beaks of the cephalopod family Histioteuthidae among others. The present study considerably expands the range of cephalopod species recorded in the diet of Cuvier's beaked whale in the Canary Islands.

Two studies have described the diet of this species in the north-east Atlantic. Desportes (1985) identified squid of the family Gonatidae among other oceanic cephalopods in the stomach contents of five Cuvier's beaked whales stranded off the French coast between 1979 and 1985 but did not provide values for their relative importance. Santos et al. (2001) analysed the stomach contents of three whales (two females and a male) stranded in Galicia (north-west Spain) and the west coast of Scotland between 1990 and 1999. Stomach contents consisted exclusively of cephalopod beaks and all the species identified were oceanic cephalopods (Teuthowenia megalops, Gonatus sp. (probaby G. fabricii), Mastigoteuthis schmidti, Histioteuthis spp., etc.). In terms of the contribution to estimated total prey biomass, squid of the family Cranchiidae were the most important component of the diet. In the present study, four species of cranchiids were recorded in Cuvier's beaked whales, comprising between $10 \%$ and $30 \%$ of prey biomass in the stomachs.

Other authors have described the stomach contents of Cuvier's beaked whales stranded in the Mediterranean (Podestà \& Meotti, 1991; Carlini et al., 1992; Lefkaditou \& Poulopoulos, 1998; Blanco \& Raga, 2000), Alaska (Foster \& Hare, 1990; Fiscus, 1997), California (Mitchell \& Houck, 1967), Texas (Fertl et al., 1997), the Dutch Antilles (Debrot \& Barros, 1994), New Zealand (Fordyce et al., 1979) and South Africa (Ross, 1984). In general the diet of this species is mainly constituted by mesopelagic or benthic deep-water cephalopods, consistent with the oceanic habitat of the whales (see Santos et al., 2001, for a review).

The existence of a fishery for Cuvier's beaked whales in Japanese waters allowed the collection of more extensive information on the diet. Nishiwaki \& Oguro (1972) record that the diet was based principally on deep-water fish and cephalopods and varied in relation to water depth and season. Cuvier's beaked whales taken in waters of more than $1000 \mathrm{~m}$ depth had mainly eaten deep-water fish while whales taken in waters less than $1000 \mathrm{~m}$ deep had eaten more cephalopods. This dietary variation led the authors to suggest that Cuvier's beaked whale is an opportunistic predator. The wide range of cephalopod species recorded in the diet in the present study would also tend to support this idea, indicating that Cuvier's beaked whale is a generalist predator feeding on any suitable prey species encountered and/or species that are locally abundant (MacLeod et al., 2003).

Information on the diet of the other beaked whale species is even more scarce. Martin et al. (1990) reported mandibles 
of the viper fish Chauliodus sloani and cephalopod beaks in the stomachs of Gervais' beaked whales stranded in the Canary Islands. Viper fish jaws were also found in the stomach of the animal examined in the present study.

Debrot \& Barros (1992) found semi-digested remains of crustaceans, fish and cephalopods in the stomach of a male Gervais' beaked whale stranded at Curaçao in the Dutch Antilles on 16 March 1990. The authors identified the mysid Gnathophausia ingens, the fish Chauliodus sloani and Nesiarchus nasutus and the cephalopods Octopoteuthis sp., Mastigoteuthis sp. and Taonius pavo. Gnathophausia ingens and cephalopod beaks were also recorded in the stomachs of two Gervais' beaked whales stranded in the same area on 20 June 1997 (Debrot et al., 1998). Cephalopod beaks were recorded from a Gervais' beaked whale stranded in the Bahamas on 20 April 1980 (Balcomb, 1981). Lastly, G. ingens was found in the stomach of a Gervais' beaked whale stranded in St Croix in the Caribbean on 12 September 1993 (Rosario-Delestre et al., 1999).

To date, the stomach contents of only three Blainville's beaked whales have been analysed. The stomach of a pregnant female stranded in South Africa on 15 February 1974 contained twenty-one otoliths from fish of the genera Scopelogadus, Lampanyctus and Cepola (Ross, 1984). The stomach of an adult female stranded in Wales (UK) on 8 July 1993 contained a single beak of Histioteuthis reversa (Herman et al., 1994). Lastly, a male Blainville's beaked whale stranded in South Africa had eaten hake, sable fish (Lepidopus caudatus), an unidentified fish and Ptrygosquilla armata (Sekiguchi, 1994). The present study concurs with Herman et al. (1994) in recording the presence of Histioteuthis reversa, along with four other oceanic squid species.

With the exception of the whales taken in Japanese waters, in most studies of beaked whale diet, no fresh remains of prey were found. Thus the importance of cephalopods in the diet could be overestimated due to the resistance of their chitinous mandibles to gastric acids and the fact that beaks from several meals could accumulate in the stomachs (Blanco \& Raga, 2000; Santos et al., 2001, etc.). It is also possible that remains of some small prey could have come from the stomachs of larger prey taken by the whales, i.e. 'secondary ingestion'. However, most of the stomachs of Cuvier's beaked whales examined in the present study contained semi-digested flesh of cephalopods (and crustaceans) as well as beaks, indicating recent feeding on cephalopods. This confirms the importance of cephalopods in the diet and seems to indicate that the whales had been feeding recently, probably during the night before the stranding took place. The presence of fresh prey remains in the stomachs is a common characteristic of animals from an atypical mass stranding. Such samples may give a more representative picture of the diet than normally obtained from stranded animals.

Little information exists on the biology of the main prey species identified in the present study. Taonius pavo has been found at a maximum depth of $2000 \mathrm{~m}$ and maximum length (DML) has been recorded as $750 \mathrm{~mm}$ (Guerra, 1992). Histioteuthis reversa has been found at depths of $1800 \mathrm{~m}$ but is also recorded from surface waters. The maximum size recorded is $185 \mathrm{~mm}$ DML (Voss et al., 1998). Mastigoteuthis schmidti has been found at depths of 50-1500 m, maximum recorded length being $120 \mathrm{~mm}$ DML (Guerra, 1992). Finally, Octopoteuthis sicula has been found from surface waters to 2000 $\mathrm{m}$ depth and the maximum recorded size is $500 \mathrm{~mm}$ DML (Guerra, 1992). Many of the cephalopod species found in the diet appear to undertake daily vertical migrations, being found in shallower waters during the night and moving to deeper waters during the day.

It is interesting to note that viperfish (Chauliodus sp.) and the squid Taonius pavo were recorded in the diet of the Gervais' beaked whales in both the Dutch Antilles (Debrot \& Barros, 1992, 1994; Debrot et al., 1998) and the Canary Islands (Martín et al. 1990, present study). Two species of Chauliodus are present in waters of the Canary Archipelago, C. sloani and $C$. danae (both with very similar mandibles, hence our identification was only to genus level). Both viperfish species are mesopelagic and bathypelagic, common in waters up to more than $1000 \mathrm{~m}$ depth. However, juvenile fish may migrate towards the surface during the night (Whitehead et al., 1989).

As mentioned above, there is limited information available on the ecology of the main prey species, and very few data on the depths at which beaked whales feed. Johnson et al. (2004) placed acoustic tags on two Cuvier's and two Blainville's beaked whales in waters of the Canary Islands, which recorded the clicks produced by the whales while echolocating. Results from the tags indicated that both species only produced clicks at depths greater than $200 \mathrm{~m}$ and up to a maximum recorded depth of $1267 \mathrm{~m}$.

It is clear that the information available on the diet of these beaked whale species is very limited. Consequently, it is important that adequate measures are put in place (for example to recover stomach contents from stranded individuals) to allow us to take every available opportunity to increase our knowledge of these enigmatic creatures.

We wish to thank Antonella Servidio, Sonia García (SECAC) and Pascual Calabuig (Wild Animal Rescue Centre, Cabildo de Gran Canaria) and members of the Pathology Department of the Veterinary School, University of Las Palmas de Gran Canaria, who assisted with the necropsies. Mónica Pérez Gil created the map used in Figure 1. Juan Carlos Moreno and Erika Urquiola helped to obtain the required permits to examine the whales.

\section{REFERENGES}

Balcomb, K.C., 1981. Ziphiid whales from the Bahamas. Bahamas Naturalist, Summer 1981, 19-22.

Blanco, C. \& Raga, J.A., 2000. Cephalopod prey of two Ziphius cavirostris (Cetacea) stranded on the western Mediterranean coast. Fournal of the Marine Biological Association of the United Kingdom, 80, 381-382.

Brown, E.G. \& Pierce, G.J., 1998. Monthly variation in the diet of harbour seals in inshore waters along the southeast Shetland (UK) coastline. Marine Ecology Progress Series, 167, 275-289.

Carlini, R., Pulcini, M. \& Würtz, M., 1992. Cephalopods from the stomachs of Cuvier's beaked whale (Ziphius cavirositris Cuvier, 1823) stranded at Fiumicino, Central Tyrrhenian Sea. In Proceedings of the Sixth Annual Conference of the European Cetacean Society, San Remo, Italy, 20-22 February 1992. European Research on Cetaceans -6 (ed. P.G.H. Evans), pp. 190-191. Cambridge: European Cetacean Society. 
Clarke, M.R., 1986a. Cephalopods in the diet of odontocetes. In Research on dolphins (ed. M.M. Bryden and R. Harrison), pp. 281321. Oxford: Clarendon Press.

Clarke, M.R. (ed.), 1986b. A handbook for the identification of cephalopod beaks. Oxford: Clarendon Press.

Debrot, A.O. \& Barros, N.B., 1992. Notes on a Gervais' beaked whale, Mesoplodon europaeus, and a dwarf sperm whale, Kogia simus, stranded in Curaçao, Netherlands Antilles. Marine Mammal Science, 8, 172-178.

Debrot, A.O. \& Barros, N.B., 1994. Additional cetacean records for the Leeward Dutch Antilles. Marine Mammal Science, 10, 359368.

Debrot, A.O., Meyer, J.A.D. \& Dezentjé, P.J.E., 1998. Additional records and a review of the cetacean fauna of the Leeward Dutch Antilles. Caribbean Fournal of Science, 34, 204-210.

Desportes, G., 1985. La nutrition des Odontocètes en Atlantique Nord-Est (côtes Françaises - Iles Feroë). PhD thesis, Université de Poitiers, Poitiers, France.

Fernández, A. et al., 2004. Beaked whales, sonar and decompression sickness. Nature, doi: 10.1038/02528.

Fernández, A. et al., 2005. "Gas and Fat Embolic Symdrome" involving a mass stranding of beaked whales (Family Ziphiidae) exposed to anthropogenic sonar signals. Veterinary Pathology, 42, $446-457$.

Fertl, D., Schiro, A.J., Collier, S. \& Worthy, G.A.J., 1997. Stranding of a Cuvier's beaked whale (Ziphius cavirostris) in Southern Texas, with comments on stomach contents. Gulf of Mexico Science, 2, 92-93.

Fiscus, C.H., 1997. Cephalopod beaks in a Cuvier's beaked whale (Ziphius cavirostris) from Amchitka Island, Alaska. Marine Mammal Science, 13, 481-486.

Fordyce, R.E., Mattlin, R.H. \& Wilson, G.J., 1979. Stranding of a Cuvier's beaked whale, Ziphius cavirostris Cuvier, 1823, at New Brighton, New Zealand. Mauri Ora, 7, 73-82.

Foster, N.R. \& Hare, M.P., 1990. Cephalopod remains from a Cuvier's beaked whale (Ziphius cavirostris) stranded in Kodiak, Alaska. Northwestern Naturalist, 71, 49-51.

Guerra, A., 1992. Mollusca, Cephalopoda. In Fauna Ibérica. Vol. 1. (ed. M.A. Ramos Sánchez et al.), Madrid: Museo Nacional de Ciencias Naturales, CSIC.

Härkönen, T.J., 1986. Guide to the otoliths of the bony fishes of the Northeast Atlantic. Hellerup: Danbui ApS.

Herman, J.S., Kitchener, A.C., Baker, J.R. \& Lockyer, G., 1994. The most northerly record of Blainville's beaked whale, Mesoplodon densirostris, from the eastern Atlantic. Mammalia, 58, 657-661.

Hernández García, V., 1995. Contribución al conocimiento bioecológico de la familia Ommastrephidae Steenstrup, 1857 en el Atlántico CentroOriental. PhD thesis, Universidad de las Palmas, Las Palmas de Gran Canaria, Spain.

Johnson, M., Madsen, P.T., Zimmer, W.M.X., de Soto, N.A. and Tyack, P.L., 2004. Beaked whales echolocate on prey. Proceedings of the Royal Society of London, Series B, Biological Sciences, 271, S383-S386.

Lefkaditou, E. \& Poulopoulos, Y., 1998. Cephalopod remains in the stomach content of beaked whales, Ziphius cavirostris (Cuvier, 1823), from the Ionian Sea. Rapport du 35 e Congrès de la Commision Internationale pour l'Exploration Scientifique de la Mer Méditerranée, 35, $460-461$.

MacLeod, G.D., Santos, M.M. \& Pierce, G.J., 2003. Review of data on diets of beaked whales: evidence of niche separation and geographic segregation. Fournal of the Marine Biological Association of the United Kingdom, 83, 651-665.
Martín, V., Vonk, R., Escorza, S. \& Montero, R., 1990. Records of Gervais' beaked whale Mesoplodon europaeus on the Canary Islands. In Proceedings of the Fourth Annual Conference of the European Cetacean Society, Palma de Mallorca, Spain, 2-4 March 1990. European Research on Cetaceans-4. (ed. P.G.H. Evans et al.), pp. 95. Cambridge: European Cetacean Society.

Martín, V., Montero, R., Heimlich-Boram, J. \& Heimlich-Boram, S. 1992. Preliminary observations of the cetological fauna from the Canary Islands. In Proceedings of the Sixth Annual Conference of the European Cetacean Society, San Remo, Italia, 20-22 February 1992. European Research on Cetaceans-6 (ed. P.G.H. Evans),. pp. 61-65. Cambridge: European Cetacean Society.

Martín V \& E. Urquiola. 2001. La observación de cetáceos. In Naturaleza de las Islas Canarias. Ecología y Conservación (ed. J.M. Fernández-Palacios and J.L.M. Esquivel), pp. 289-295. Sta. Cruz de Tenerife: Turquesa Publicaciones.

Merella, P., Quetglas, A., Alemany, F. \& Carbonell, A., 1997. Length-weight relationship of fishes and cephalopods from the Balearic Islands (western Mediterranean). Naga ICLARM, 20, 66-68.

Mitchell, E. \& Houck, W., 1967. Guvier's beaked whale (Ziphius cavirostris) stranded in Northern California. Fournal of the Fisheries Research Board of Canada, 24, 2503-2513.

Nishiwaki, M. \& Oguro, N., 1972. Catch of the Cuvier's beaked whales off Japan in recent years. Scientific Reports of the Whales Research Institute, 24, 35-41.

Omura, H., Fujino, K. \& Kimura, S., 1955. Beaked whale Berardius bairdi of Japan, with notes on Ziphius cavirostris. Scientific Reports of the Whales Research Institute, 10, 89-132.

Podestà, M. \& Meotti, C., 1991. The stomach contents of a Cuvier's beaked whale Ziphius cavirostris, and a Risso's dolphin Grampus griseus, stranded in Italy. In Proceedings of the Fifth Annual Conference of the European Cetacean Society, Sandefjord, Norway, 21-23 February 1991. European Research on Cetaceans - 5 (ed. P.G.H. Evans), pp. 58-61. Cambridge: European Cetacean Society.

Rossario-Delestre, R.J., Rodriguez-Lopez, L., Mignucci-Giannoni, A. \& Mead,J.G., 1999. New records of beaked whales (Mesoplodon spp.) for the Caribbean. Caribbean Fournal of Science, 35, 144-148.

Ross, G.J.B., 1984. The smaller cetaceans of the south east coast of southern Africa. Annals of the Cape Provincial Museums (Natural History), 15, 173-410.

Santos, M.B, Pierce, G.J., Herman, J. López, A., Guerra, A., Mente, E. \& Clarke, M.R., 2001. Feeding ecology of Cuvier's beaked whale (Ziphius cavirostris): a review with new information on diet of this species. Fournal of the Marine Biological Association of the United Kingdom, 81, 687-694.

Sekiguchi, K., 1994. Studies on feeding habits and dietary analytical methods for smaller odontocete species along the southern African coast. Ph.D. Thesis, University of Pretoria, Pretoria, South Africa.

Smale, M.J., Watson, G. \& Hecht, T., 1995. Otolith atlas of southern African marine fishes. Ichthyological Monographs of the 7.L.B. Smith Institute of Ichthyology, 1, xiv, 253 pp.

Voss, N.A., Nesis. K.N. \& Rodhouse, P.G., 1998. The cephalopod family Histioteuthidae (Oegopsida): systematics, biology, and biogeography. Smithsonian Contributions to Zoology, 586, 293-372.

Whitehead, P.J.P., Bauchot, M.-L., Hureau, J.-C., Nielsen, J. \& Tortonese, E., (eds.), 1989. Fishes of the North-eastern Atlantic and the Mediterranean. UNESCO, Paris. 1461 pp.

Submitted 18 May 2006. Accepted 18 September 2006. 